\title{
Effects of genetic screening on perceptions of health: a pilot study
}

Theresa M Marteau, Monica van Duijn, Ian Ellis

\begin{abstract}
The aim of the current study was to determine how carriers of a recessive gene, which confers no risk to their own health, perceive their health, relative to noncarriers. Perceptions of health in three groups were compared: those screened and found to carry the gene for TaySachs disease, those screened and not found to carry the gene for Tay-Sachs disease, and a community based sample who, it was presumed, had not undergone screening. The groups did not differ in their perceptions of their current health or their past health. Carriers, however, viewed their future health with less optimism than the other two groups. The causes and consequences of this altered perception need to be explored in future studies. With the advent of population based screening for cystic fibrosis carrier status, these results highlight the importance of assessing in detail people's experiences of screening before the introduction of any mass genetic screening programmes.
\end{abstract}

Biogenetic developments now make it possible to give people very specific information about their risks of developing certain genetic diseases as well as the risks of passing these on to their children. Until recently this type of information was mainly available to those at increased risk of developing or passing on a genetic disease to offspring, identified from a family history of an inherited disorder or ethnic origin. After the detection of the commonest gene mutation for cystic fibrosis, ${ }^{1}$ the most frequent recessive gene disorder among northern Europeans, population based screening is likely to be made available.

This means that a screening test will be made available to a whole population who hitherto were unlikely to have considered themselves at risk for carrying a genetic disorder. It is therefore opportune to consider the implications of this for those who participate in any such screening programme.

Providing information about genetic make up changes how people are viewed by others. For example, as a result of the screening programmes for sickle cell trait in the United States, health insurance companies charged higher premiums for carriers, and the US Army considered no longer employing them. ${ }^{23}$ Other unintended adverse effects of genetic screening were evident in a pilot screening project in Greece for haemoglobinopathies: carriers were stigmatised by the community and were considered eligible for marriage only by other carriers. ${ }^{4}$ In a more recent study, noncarriers of sickle cell trait perceived carriers as less happy, less healthy, and less active than did carriers. ${ }^{5}$

Providing information about genetic make up may also change how people view themselves, in particular their health. This may be so for both carriers and non-carriers, but the effects are likely to be more marked for carriers. For example, $43 \%$ of parents of children found to be sickle cell carriers thought of their children as having a disease, with $66 \%$ of these parents thinking that their children needed dietary supplements to stay healthy. ${ }^{6}$ Sickle cell trait is not normally associated with clinical problems, but very occasionally it can manifest under conditions of severe hypoxic stress. It is unclear therefore whether negative attitudes towards carriers arise from this medical concern, or whether it reflects a more general prejudice against carriers of a genetic disease.

So far, there have been no studies of whether undergoing genetic screening alters how people view their health. There is some evidence from other health screening programmes that undergoing screening can undermine people's view of their health. For example, on occasions, undergoing screening has served to reassure people falsely about their health ${ }^{7}$; on other occasions it has inappropriately alarmed even those with a negative result. ${ }^{8}$ The aim of the current study is to determine how carriers of a recessive gene, which confers no risk to their own health, perceive their health, relative to non-carriers.

\section{Subjects}

The subjects comprised three groups who had been screened for Tay-Sachs disease carrier status. One group of 50 subjects had been screened opportunistically 16 months earlier, when they attended a cultural exhibition for the Jewish community, and received a negative result. A further 50 people had received a negative result 16 months earlier, after attending a designated screening event in a local synagogue after extensive community advertising. The third group of 43 people had been screened over the last three years and found to be carriers for Tay-Sachs disease. This group included relatives, both Jewish and non-Jewish, of previously affected children $(n=8)$, and previously identified carriers for Tay-Sachs disease $(n=8)$, as well as persons identified by routine screening $(n=27)$. Thus this carrier group is drawn from a more heterogeneous 
source than the non-carriers. Twenty-seven of the carriers $(63 \%)$ and 55 of the non-carriers $(55 \%)$ responded to the questionnaire. The mean age of the non-carriers was 29 years (SD $7 \cdot 2$ ) and for the carriers it was 39.5 (SD 14.0).

The comparison group comprised consecutive attenders at a community education centre in London. Of the 55 adults who were approached, two refused and one questionnaire was not sufficiently complete for the analysis. It was assumed that this sample was not at a higher risk than the general population for genetic disease. The mean age of this sample was 34 years (SD 9.8).

\section{Measures}

PERCEIVED HEALTH

This was measured using a five item questionnaire which measured perceived health from three time perspectives: current health, past health, and future health. Questions 1 and 3 were taken from the SF-36 Health Status Questionnaire (Quality Crest Inc, 1989). The remaining questions were written specifically for the study. The questions asked were as follows.

(1) In general would you say your health is: poor, fair, good, excellent?

(2) I worry about my health: strongly agree, agree, neither agree nor disagree, disagree, strongly disagree.

(3) Compared to two years ago, how would you rate your health now: much better, somewhat better, the same, somewhat worse, much worse?

(4) In two years' time do you expect your health to be: much better, somewhat better, the same, somewhat worse, much worse?

(5) What do you think is your risk of developing something wrong in the future, compared with other people your age and sex?

\section{Procedure}

Those who had undergone screening for the Tay-Sachs disease gene were sent a questionnaire by post, with a covering letter from the genetics centre running the screening programme in which they had participated. All replies were made anonymously. Those in the control group were asked to join the study and complete a questionnaire when they attended a community education centre in London.

\section{Results}

There were no differences between the three groups in how they perceived their current health. Over $80 \%$ of subjects in each group perceived their health as good or excellent (table). Similarly, there were no differences between carriers of Tay-Sachs disease, known non-carriers, and the control group in whether they worried about their current health: only a minority in each group claimed to worry about this. Contrasting current health with health
Responses ( $\%)$ of carriers $(n=27)$, non-carriers $(n=55)$, and controls $(n=52)$ to each of the five questions assessing perceived health.

\begin{tabular}{|c|c|c|c|c|}
\hline & Carriers & $\begin{array}{l}\text { Non- } \\
\text { carriers }\end{array}$ & Controls & \\
\hline $\begin{array}{l}\text { Description of current } \\
\text { health } \\
\text { Excellent } \\
\text { Good } \\
\text { Fair } \\
\text { Poor }\end{array}$ & $\begin{array}{r}41 \\
59 \\
0 \\
0\end{array}$ & $\begin{array}{r}40 \\
46 \\
14 \\
0\end{array}$ & $\begin{array}{r}23 \\
60 \\
15 \\
2\end{array}$ & \\
\hline $\begin{array}{l}\text { Worry about current } \\
\text { health? } \\
\text { Yes } \\
\text { No } \\
\text { Don't know }\end{array}$ & $\begin{array}{l}15 \\
55 \\
30\end{array}$ & $\begin{array}{l}33 \\
40 \\
27\end{array}$ & $\begin{array}{l}27 \\
50 \\
23\end{array}$ & \\
\hline $\begin{array}{l}\text { Current health, } \\
\text { compared with } \\
2 \text { years ago } \\
\text { Better } \\
\text { Same } \\
\text { Worse }\end{array}$ & $\begin{array}{l}18 \\
70 \\
12\end{array}$ & $\begin{array}{l}15 \\
70 \\
15\end{array}$ & $\begin{array}{l}23 \\
65 \\
12\end{array}$ & \\
\hline $\begin{array}{l}\text { Expectation of health } \\
\text { in } 2 \text { years time } \\
\text { Better } \\
\text { Same }\end{array}$ & $\begin{array}{r}7 \\
89\end{array}$ & $\begin{array}{l}20 \\
78\end{array}$ & $\begin{array}{l}38 \\
58\end{array}$ & ${ }^{*} \mathrm{p}<0.01$ \\
\hline $\begin{array}{l}\text { Risk of illness } \\
\text { compared with others } \\
\text { of similar age and sex } \\
\text { Lower } \\
\text { Same }\end{array}$ & $\begin{array}{r}7 \\
85\end{array}$ & $\begin{array}{l}20 \\
69\end{array}$ & $\begin{array}{l}32 \\
61\end{array}$ & $+\mathrm{p}<0.05$ \\
\hline
\end{tabular}

* These responses do not sum up to $100 \%$ because those responding 'worse' were excluded from the $\chi^{2}$ analysis. + These responses do not sum up to $100 \%$ because those responding 'higher' were excluded from the $\chi^{2}$ analysis.

status two years previously showed no differences between the groups, most people perceiving their health to be unaltered. The groups differed however in their expectations about their future health. Given the small numbers in some of the groups, these following two analyses were conducted by comparing the number of subjects who perceived their health as remaining the same with those who felt it would get better, and the number of subjects who perceived their risk of developing illness as similar to others with those who saw their risks as lower. Carriers of the Tay-Sachs disease gene held the least optimistic view of their future health compared with the other two groups $\left(\chi^{2}=10.63, \mathrm{df}=2, \mathrm{p}<0.01\right)$. Similarly, carriers were less optimistic about their risk of developing something wrong in the future $\left(\chi^{2}=6.56, \mathrm{df}=2, \mathrm{p}<0.05\right)$. For example, only $7 \%$ of carriers perceived their risk as lower than average, compared with $20 \%$ of non-carriers and $32 \%$ of the control group.

\section{Discussion}

The results of this study suggest that learning that one is a carrier of a gene for a recessive genetic disorder changes people's views about their future health. This may be because these carriers (erroneously) consider that their future health will be jeopardised by the presence of an abnormal gene.

In a study of over 1000 people attending for Tay-Sachs disease screening in the USA, 45\% stated that it would matter a great deal to them if they were found to be carriers. ${ }^{9} \mathrm{McQueen}^{9}$ was surprised at this finding stating that "Knowing the recessive character of the disease, one would assume that being a carrier would not matter so highly, for it is true that 
most individuals carry many recessive traits any one of which might be lethal in combination with a spouse who is a carrier of the same trait" (p133). In an eight year follow up of those found to be carriers in a Tay-Sachs disease screening programme in Canada, 19\% of carriers reported feeling some anxiety about this. ${ }^{10}$

Measuring people's knowledge and beliefs about carrier status in future studies would shed more light on why being a carrier matters so much. At the root of many of the problems encountered by those participating in various screening programmes is a poor understanding of the tests they have undergone. ${ }^{11}$ This is likely to be a particular problem for those undergoing genetic screening, given the generally poor level of scientific understanding in the general population. ${ }^{1213}$ If this explanation were true, then providing more information before and after screening to carriers may prevent this reduced optimism about the future.

An alternative explanation for the findings in the current study is that receipt of one piece of bad news about one's health (that is, learning that one is a carrier) reduces the general tendency for people to be optimistic when considering their chances of becoming ill or experiencing any misfortune. ${ }^{14}$ It is not known what implications, if any, viewing the future with a less rosy glow than average may have. On the one hand, carriers, with their more realistic views of future health, may be more likely to adopt a healthy life style compared with non-carriers and controls. Alternatively, the loss of an optimistic view of the future may make it more difficult for carriers to cope with the uncertainty that inevitably surrounds the future. This is a question needing further empirical investigation.

We do not know what impact, if any, receipt of information about carrier status had upon people's reproductive intentions or behaviour, nor whether it affected their decision to marry or their choice of marriage partner. Several studies provide evidence that knowledge of carrier status affects reproductive behaviour, ${ }^{15-17}$ although sometimes these changes are very small. ${ }^{18} 19$

The sample in this study was small and is not representative of the general population. Those who underwent screening differed from the comparison group in at least two respects: ethnic background and the fact that they had undergone a genetic screening test. Not all of the carriers were from the same sample as those who received a negative test result. It is possible that they may have differed in ways other than carrier status (such as a family history of the disease) which may have accounted for the differences observed between the groups. Future studies using larger and more representative groups are needed to determine the generalisability of the results.

Bearing in mind these limitations, the results of this pilot study suggest that learning one is a carrier for a genetic disease can have subtle, unintended effects upon a person's selfperception. With the advent of population based screening for cystic fibrosis carrier status, and in the near future other genetic diseases, these results highlight the importance of assessing in detail people's experiences of undergoing screening before the introduction of any mass screening programmes. Only in this way will we know the full implications of conducting genetic screening, a prerequisite to determining whether the benefits of population based screening will outweigh the harm.

1 Riordan JR, Rommens JA, Kerem B et al. Identification of the cystic fibrosis gene: cloning and characterization of complementary DNA. Science 1989;245:1066-73.

2 Beutler E, Boggs DR, Heller P, Mauer A, Motulsky AG Sheeny TW. Hazards of indiscriminate screening for sickling. N Engl f Med 1971;285:1485-6.

3 Reilly P. Genetics, law and social policy. Cambridge, MA Harvard University Press, 1977.

4 Stamatoyannopoulus G. Problems of screening and counselling in the hemoglobinopathies. In: Motulsky AG, Ebling FJG, eds. Birth defects. Proceedings of the Fourth International Conference. Vienna: Excerpta Medica, 1974:268-76.

5 Wooldrige EQ, Murray RF. The health orientation scale: a measure of feeling about sickle cell trait. Soc Biol 1989;35:123-36.

6 Hampton ML, Anderson J, Lavizzo BS, Bergman AB Sickle cell 'nondisease': a potentially serious public health problem. Am J Dis Child 1974;128:58-61.

7 Tymstra T, Bieleman B. The psychosocial impact of mass screening for cardiovascular risk factors. Fam Pract 1987;4:287-90.

8 Stoate HG. Can health screening damage your health? $f R$ Coll Gen Pract 1989;39:193-5.

9 McQueen DV. Social aspects of genetic screening for TaySachs disease: the pilot community screening program in Baltimore and Washington. Soc Biol 1975;22:125-33.

10 Zeesman S, Clow CL, Cartier L, Scriver CR. A private view of heterozygosity: eight-year follow-up on carriers of Tay-Sachs gene detected by high school screening. $A m \mathcal{F}$ Tay-Sachs gene detected by
Med Genet 1984;18:769-78.

11 Marteau TM. Screening in practice: reducing the psychological costs. $B M \mathcal{J}$ 1990;301:26-8.

12 Durant JR, Evans GA, Thomas GP. The public underurant JR, Evans GA, Thomas GP. The publ

13 Weatherall $\mathrm{D}$. Introduction. In: Weatherall $\mathrm{D}$, Shelley JH, eds. Social consequences of genetic engineering. Amsterdam Elsevier Sciences Publishers, 1989:1-18.

14 Weinstein ND. Why it won't happen to me: perceptions of risk factors and susceptibility. Health Psychology 1984;3:431-57.

15 Modell B, Ward RHT, Fairweather DVI. Effect of introducing antenatal diagnosis on the reproductive behaviou of families at risk of thalassaemia major. BMY 1980;2:737

16 Harper PS, Tyler A, Smith S, et al. Decline in the predicted incidence of Huntington's chorea associated with systemincidence of Huntington's chorea associated with system1981;i:411-13.

17 Knott PD, Penketh RJA, Lucas MK. Uptake of amniocentesis in women aged 38 years or more by the time of the expected date of delivery: a two-year retrospective study. Br 7 Obstet Gynaecol 1986;93:1246-50.

18 Evers-Kiebooms G, Denayer L, Berghe H. A child with cystic fibrosis. II. Subsequent family planning decisions, reproduction and use of prenatal diagnosis. Clin Genet 1990;37:207-15.

19 Sujansky E, Kreutzer SB, Johnson AM, Lezotte DC, Schrier RW, Gabow PA. Attitudes of at-risk and affected individuals regarding pre-symptomatic testing for autosomal dominant polycystic kidney disease. Am $\mathcal{F}$ Med Gene 1990;35:510-15. 